\title{
Let's move our next generation of patients toward healthy behaviors
}

\author{
This article was published in the following Dove Press journal: \\ Journal of Multidisciplinary Healthcare \\ 16 April 2012 \\ Number of times this article has been viewed
}

\author{
Phyllis A Nsiah-Kumi ${ }^{1,2}$ \\ Lydia Y Kang' \\ Jennifer R Parker ${ }^{1,2}$ \\ 'General Internal Medicine, ${ }^{2}$ Internal \\ Medicine-Pediatrics Program, \\ University of Nebraska Medical \\ Center, Omaha, NE, USA
}

\begin{abstract}
Health care professionals in all disciplines who care for adults have the opportunity to improve the health of the next generation. The prevalence of overweight and obesity continues to rise in children and adults around the world. As providers caring for adults, our primary goal is to address the health needs of our patients. However, it is important to recognize that counseling our patients who have children can lead them to adopt model behaviors that will be imitated by their children (and therefore improve the weight status and reduce health risks for their children). Additionally, many patients are more motivated to adopt behavior changes for the sake of their children than for their own health. All of 2012's 11-year-old children may be our adult patients in 10 years - especially if they have already developed weight-related health problems. Anything we do to address childhood obesity is an investment in the health of our patient panels, both now and in the future. While counseling may feel futile at times, there is strong evidence for the power of counseling to shape patient behavior. Counseling adult patients about healthy behaviors will benefit not only our patients today but our patients in the future as well.
\end{abstract}

Keywords: obesity, counseling, provider, lifestyle change, parental modeling, self-efficacy

\section{Introduction}

On February 9, 2010, Michelle Obama, the First Lady of the United States, declared war on childhood obesity. The Let's Move! Campaign is an ambitious national initiative to eliminate childhood obesity within a generation.

While childhood obesity may seem like a pediatrician or primary care practitioner's challenge, it is, in fact, a public health problem that providers caring for adults can tackle in their patient encounters as well. ${ }^{1}$ In fact, several US organizations representing the community of health care providers pledged their support to this initiative when it began two years ago. ${ }^{2-7}$

The statistics are sobering with one in three adults and half of children in the US being overweight or obese, no matter the health care discipline, we have our work cut out for us. ${ }^{8,9}$ In the US, up to $50 \%$ of obese 6 year olds and $80 \%$ of obese $10-14$ year olds who have an obese parent will become obese young adults. ${ }^{10}$ For young children with an obese parent, the risk of being obese as an adult is increased threefold. If both parents are obese, a child's risk of obesity in adulthood is increased tenfold. Prepregnancy obesity and excess pregnancy weight gain are also associated with childhood obesity and obesity later in life. ${ }^{11}$ Childhood obesity is an important risk factor for significant adult morbidity and premature mortality, and the importance of addressing it cannot be underestimated. ${ }^{12-14}$
Correspondence: Phyllis A Nsiah-Kumi Internal Medicine-Pediatrics, University of Nebraska Medical Center 984085 Nebraska Medical Center, Omaha, NE 68I98-4085, USA

$\mathrm{Tel}+\mathrm{I} 4025596946$

Fax + I 4025596 II 3

Email pnkumi@unmc.edu 
On a daily basis, we work to encourage our patients to change their health behaviors. We are no strangers to discussing healthy dietary choices and increasing physical activity. For our patients who have children on the way or in their homes, an important part of our counseling efforts should be to remind them that, no matter which behaviors they select, their behaviors impact those children. Either they are modeling behaviors for their children or, in the case of pregnant patients, they are actually programming their children's weight status for the future. ${ }^{15-17}$

Studies show that parental modeling plays an important role in the behaviors that children adopt. ${ }^{18-20}$ It is interesting to note that parents will often change their behaviors to benefit their children's health, although they may not make the changes based on concerns for their own health. ${ }^{21}$ An effective counseling strategy may be to emphasize children's health risks; this may serve as a catalyst for behavior change in the parent, with hope of improved risk profiles and subsequent and parallel behavior changes in their children. ${ }^{22}$ When our adult patients make those changes for themselves, they can reap the amazing benefits of seeing their behaviors impact the entire family. We as adult providers can also see our efforts impact entire families.

For example, take $\mathrm{Mr} \mathrm{O}$, a patient seen in our general internal medicine clinic. At the age of 33 years, $\mathrm{Mr} \mathrm{O}$ was $22.7 \mathrm{~kg}$ overweight and came into our general internal medicine clinic after being referred for an elevated glucose level on a routine blood test. His story in many ways was classic. He had polydipsia, polyuria, and a history of weight gain over the last several years. His initial glycosylated hemoglobin was $11.7 \%$. We knew that we had our work cut out for us. The nemesis of every internist - the never-ending quest for successful lifestyle changes - was staring us in the face.

When we broke the news of his new diagnosis of type 2 diabetes and gathered additional history, we found that $\mathrm{Mr} \mathrm{O}$ worked as a cook in two restaurants. He worked 90-hour weeks to provide for his family. In his hectic schedule, there was hardly time for exercise, and all of his meals came from the kitchens in which he worked (where fried foods abounded on the menus). While he was very concerned about his own health, Mr O lamented that his children were also gaining too much weight.

We counseled him on lifestyle changes. With regard to diet, we learned that most of the food he ate was what was at work - fattening, fried, and carbohydrate-heavy. We recommended that he restrict his carbohydrates to 3-4 cholesterol units per meal, increase the amount of vegetables in his diet, eat a reasonable amount of low-fat dairy and lean protein, and cut out the deep-fried foods. He said that even though he was surrounded by poor food choices at work, he was motivated by his new diagnosis to eat less carbohydrates and decrease his caloric intake. He cleared out a lot of unhealthy food out of his home, thus affecting how his children and spouse ate too.

With regards to physical activity, we discussed how much exercise he did. True "exercise" was minimal, but he was on his feet all day so he was relatively active. He worked as a short-order cook and had very little time to exercise, though he promised to find more time to do so. We emphasized making specific small steps. He resolved to do more walking, particularly with his family.

After listening to our recommendations on diet and exercise, arranging for an appointment with a dietician, and collecting his prescription for metformin, he said goodbye with a promise to change his lifestyle. We had heard it before, but we hoped for the best.

One month later, $\mathrm{Mr} \mathrm{O}$ returned for a follow-up visit. To our great surprise, he had already lost $2.7 \mathrm{~kg}$, and his fasting glucose levels were in the normal range. He continued his efforts diligently. Six months later and $22.7 \mathrm{~kg}$ lighter, he was off metformin and boasting glycosylated hemoglobin of $5.0 \%$. He was eating moderate portions of healthy foods, and he had increased his physical activity level.

To our delight, he reported that his children replaced fattening and starchy foods with fruits and vegetables and increased their physical activity, modeling his behavior. They began to lose weight as well. His story became well known in his community. Women stopped him on the street and asked what his secret was to managing his weight and beating diabetes. He told them proudly about portion control and increased physical activity, and they listened.

\section{Discussion}

$\mathrm{Mr} \mathrm{O}$ is a wonderful real-life example of the impact one patient's behavior change can have on his family and his community. And he was spurred to that behavior change by the words of his internist. Counseling patients regarding lifestyle change can be a frustrating and challenging part of an adult health care provider's job, but we shouldn't give up. Counseling patients regarding healthy weights, related health risks, and healthy behavior choices is an important part of the work we do and is recommended by clinical guidelines. ${ }^{23-28}$

Studies have shown that patients with obesity often do not receive counseling regarding their weight in clinical encounters. ${ }^{29,30}$ Behavior change is essential to improved health for our patients. As we counsel them to adopt healthy behaviors 
for themselves, we have a phenomenal opportunity to impact their children as well. If you are not a pediatric provider, you may be saying to yourself, "I did not choose pediatrics or family medicine. I chose to care for adults." Perhaps despite the fact that you selected to care for adults, the job does not end with the patient in front of you. Environmental factors, health literacy, socioeconomic status, and many other factors impact our patients' ability to adopt recommended behavior changes. ${ }^{31-33}$ However, the power of counseling in a clinical setting cannot be underestimated. ${ }^{34-36}$

Our patients have tremendous power to impact the next generation's health. ${ }^{18,37}$ As we counsel our patients to change their health behaviors, we have the power to impact the next generation's health as well. Perhaps an added emphasis on their children's risk may be an important motivator for behavior change in our patients.

It is also essential to remember that an obese 11-year-old is likely to be overweight or obese as an adult, and in 10 years may be an adult patient. This will especially be true if (s)he has already developed comorbid conditions. An investment in the health of the next generation is also an investment in the health of our future patients. Adult patients do not acquire all of their health risks the day they become 21 years old and enter our care. Health risk accumulates throughout the life course, ${ }^{1}$ and the health problems of today's youth and adolescents will be the health problems of our cardiovascular risk-laden young adults in a decade or so.

Reinforcement of these important health messages by health care providers in all disciplines is essential. Patients often have greater concern about their weight or their children's weights when they have been counseled about weight by a health care provider. ${ }^{38}$ Whether you are a nurse, pharmacist, obstetrician-gynecologist, pediatrician, adult primary care provider, subspecialist, psychiatrist, physical therapist, dietician, dentist, or other health professional, there is a role for you. ${ }^{39-47}$

The evidence suggests that we do not do counsel patients often enough or with great skill. ${ }^{4-53}$ The evidence also suggests that a multidisciplinary strategy is essential to success. ${ }^{54-56}$ So, let's counsel our patients about healthy weights and healthy behaviors. Let's talk to our patients about the impact of their behaviors on their children's weight and health. In each of our disciplines, let's teach our trainees to do the same. Ensuring that the next generation of multidisciplinary health care providers is prepared to counsel patients on these issues increases our future patients' chances of successful behavior change. ${ }^{35,57-65}$
Let's try something a little different and see what happens. Let's move the next generation toward healthier behaviors and reduce the impact of obesity on the health of our patients, their families and our nations. The obesity statistics are staggering. We have a lot of work to do.

\section{Acknowledgments}

Special thanks to Dr Rita J Black and Ms Delicia Gaines for their technical assistance with the preparation of this manuscript.

\section{Disclosure}

The author reports no conflicts of interest in this work.

\section{References}

1. Wojcicki JM, Heyman MB. Let's Move - childhood obesity prevention from pregnancy and infancy onward. N Engl J Med. 2010;362(16): $1457-1459$.

2. American Academy of Family Practice. Academy joins campaign against childhood obesity [article on the Internet]. Leawood, KS: American Academy of Family Practice; c2011 [updated February 12, 2010]. Available from: http://www.aafp.org/online/en/home/publications/ otherpubs/w4u.html. Accessed May 7, 2011.

3. American Academy of Pediatrics. AAP president joins First Lady Michelle Obama in commitment to reduce childhood obesity [article on the Internet]. Elk Grove Village, IL: American Academy of Pediatrics; 2010. Available from: http://www.aap.org/obesity/ whitehouse/PalfreyObesityInitiativePR.pdf. Accessed May 8, 2011.

4. American Dietetic Association. ADA supports Michelle Obama's childhood obesity initiative [article on the Internet]. Chicago, IL: American Dietetic Association; c 1995-2011. Available from: http://www.eatright. org/Public/content.aspx?id=4294967969. Accessed May 7, 2011.

5. American Medical Association. Childhood Obesity American Medical Association (AMA) Policy and Guidelines. Chicago, IL: American Medical Association; c2011 [updated 2010]. Available from: http:// www.ama-assn.org/resources/doc/public-health/ama-policieschildhood-obesity.pdf. Accessed March 3, 2011.

6. Children Now, Oral Health Access Council. Oral health and obesity policy brief [report on the Internet]. Oakland, CA: Children Now; c2011 [updated February 20, 2011]. Available from: http://www.childrennow. org/uploads/documents/oral_health_brief_022011.pdf. Accessed March 18, 2011

7. Waldman R. Working together to reduce obesity in America. ACOG's Legislative News [article on the Internet]. Washington DC: American College of Obstetrics and Gynecology; c2011 [updated July 27, 2010]. Available from: http://www.acog.org/departments/govtrel/ InsideScoop20100727.pdf. Accessed February 27, 2011.

8. Ogden CL, Carroll MD, Curtin LR, McDowell MA, Tabak CJ, Flegal KM. Prevalence of overweight and obesity in the United States, 1999-2004. JAMA. 2006;295(13):1549-1555.

9. Singh G, Kogan M, van Dyck P. Changes in state-specific childhood obesity and overweight prevalence in the United States from 2003 to 2007. Arch Pediatr Adolesc Med. 2010;164(7):E1-E10.

10. Whitaker RC, Wright JA, Pepe MS, Seidel KD, Dietz WH. Predicting obesity in young adulthood from childhood and parental obesity. NEngl J Med. 1997;337(13):869-873.

11. Melzer K, Schutz Y. Pre-pregnancy and pregnancy predictors of obesity. Int $J$ Obes. 2010;34(S2):S44-S52.

12. Franks PW, Hanson RL, Knowler WC, Sievers ML, Bennett PH, Looker HC. Childhood obesity, other cardiovascular risk factors, and premature death. $N$ Engl J Med. 2010;362(6):485-493. 
13. Must A, Jacques PF, Dallal GE, Bajema CJ, Dietz WH. Long-term morbidity and mortality of overweight adolescents. A follow-up of the Harvard Growth Study of 1922 to 1935. N Engl J Med. 1992;327(19): $1350-1355$.

14. Freedman DS, Dietz WH, Srinivasan SR, Berenson GS. The relation of overweight to cardiovascular risk factors among children and adolescents: the Bogalusa Heart Study. Pediatrics. 1999;103(6 Pt 1): $1175-1182$.

15. Legler J, Hamers T, van Eck van der Sluijs-van de Bor M, et al. The OBELIX project: early life exposure to endocrine disruptors and obesity. Am J Clin Nutr. 2011:94(Suppl 6):1933S-1938S.

16. Lau C RJ, Desai M, Ross MG. Fetal programming of adult disease: implications for prenatal care. Obstet Gynecol. 2011;117(4):978-985.

17. Nsiah-Kumi PA, Ariza AJ, Mikhail LM, Feinglass J, Binns HJ. Family history and parents' beliefs about consequences of childhood overweight and their influence on children's health behaviors. Acad Pediatr. 2009; 9(1):53-59.

18. Tibbs T, Haire-Joshu D, Schechtman KB, et al. The relationship between parental modeling, eating patterns, and dietary intake among African-American parents. J Am Diet Assoc. 2001;101(5):535-541.

19. Campbell KJ, Crawford DA, Ball K. Family food environment and dietary behaviors likely to promote fatness in 5-6 year-old children. Int J Obes (Lond). 2006;30(8):1272-1280.

20. Golan M. Parents as agents of change in childhood obesity - from research to practice. Int J Pediatr Obes. 2006;1(2):66-76.

21. Borrelli B, McQuaid EL, Becker B, et al. Motivating parents of kids with asthma to quit smoking: the PAQS project. Health Educ Res. 2002;17(5):659-669.

22. Gardner B, Wardle J, Poston L, Croker H. Changing diet and physical activity to reduce gestational weight gain: a meta-analysis. Obes Rev. 2011;12(7):e602-e620.

23. Krebs NF, Jacobson MS. American Academy of Pediatrics Committee on Nutrition. Prevention of pediatric overweight and obesity. Pediatrics. 2003;112(2):424-430.

24. Daniels S, Jacobson M, McCrindle B, Eckel R, Sanner B. AHA conference proceedings. American Heart Association childhood obesity research summit report. Circulation. 2009;119(15):e489-e517.

25. American Dietetic Association (ADA). Adult Weight Management Evidence-based Nutrition Practice Guideline. Chicago, IL: American Dietetic Association; 2006.

26. August GP, Caprio S, Fennoy I, et al. Prevention and treatment of pediatric obesity: an Endocrine Society clinical practice guideline based on expert opinion. J Clin Endocrinol Metab. 2008;93(12):4576-4599.

27. National Heart Lung, and Blood Institute, National Institutes of Health. Clinical guidelines on the identification, evaluation, and treatment of overweight and obesity in adults - the evidence report. Obes Res. 1998; 6(Supp1 2):51S-209S.

28. US Preventive Services Task Force. Screening for obesity in children and adolescents: US Preventive Services Task Force recommendation statement. Pediatrics. 2010;125(2):361-367.

29. Tham M, Young D. The role of the general practitioner in weight management in primary care - a cross sectional study in general practice. BMC Fam Pract. 2008;9(1):66.

30. Heywood A, Firman D, Sanson-Fisher R, Mudge P, Ring I. Correlates of physician counseling associated with obesity and smoking. Prev Med. 1996;25(3):268-276.

31. Lucan SC, Barg FK, Long JA. Promoters and barriers to fruit, vegetable, and fast-food consumption among urban, low-income African Americans - a qualitative approach. Am J Public Health. 2010;100(4): 631-635.

32. Seligman H, Wallace A, DeWalt D, et al. Facilitating behavior change with low-literacy patient education materials. Am J Health Behav. 2007;31(Suppl 1):S69-S78.

33. Sonneville K, La Pelle N, Taveras E, Gillman M, Prosser L. Economic and other barriers to adopting recommendations to prevent childhood obesity: results of a focus group study with parents. BMC Pediatr. 2009;9:81
34. Jay M, Gillespie C, Schlair S, Sherman S, Kalet A. Physicians' use of the $5 \mathrm{As}$ in counseling obese patients: is the quality of counseling associated with patients' motivation and intention to lose weight? BMC Health Serv Res. 2010;10(1):159.

35. Thande NK, Hurstak EE, Sciacca RE, Giardina E-GV. Management of obesity: a challenge for medical training and practice. Obesity. 2008;17(1):107-113.

36. Wilson DB, Johnson RE, Jones RM, Krist AH, Woolf SH, Flores SK. Patient weight counseling choices and outcomes following a primary care and community collaborative intervention. Patient Educ Couns. 2010;79(3):338-343.

37. Hood M, Moore LL, Sundarajan-Ramamurti A, Singer M, Cupples LA, Ellison RC. Parental eating attitudes and the development of obesity in children. The Framingham Children's Study. Int J Obes Relat Metab Disord. 2000;24(10):1319-1325.

38. Post RE, Mainous AG III, Gregorie SH, Knoll ME, Diaz VA, Saxena SK. The influence of physician acknowledgment of patients' weight status on patient perceptions of overweight and obesity in the United States. Arch Intern Med. 2011;171(4):316-321.

39. Shirazian T, Raghavan S. Obesity and pregnancy: implications and management strategies for providers. Mt Sinai J Med. 2009;76(6): 539-545.

40. Morris D, Kitchin EM, Clark DE. Strategies for optimizing nutrition and weight reduction in physical therapy practice: the evidence. Physiother Theory Pract. 2009;25(5-6):408-423.

41. Semmler C, Semmler M. Counseling the coronary patient. Am J Occup Ther. 1974;28(10):609-614.

42. ter Bogt NC, Milder IE, Bemelmans WJ, et al. Changes in lifestyle habits after counselling by nurse practitioners: 1-year results of the Groningen Overweight and Lifestyle study. Public Health Nutr. 2011; 14(06):995-1000.

43. Dastani HB, Brown CM, O'Donnell DC. Combating the obesity epidemic: community pharmacists' counseling on obesity management. Ann Pharmacother. 2004;38(11):1800-1804.

44. Holtzman D, Burke J. Nutritional counseling in the chiropractic practice: a survey of New York practitioners. J Chiropr Med. 2007;6(1):27-31.

45. Ferguson J. Dietitians as behavior - change agents. J Am Diet Assoc. 1978;73(3):231-238.

46. Hellwig T, Stoebner L, Johnson A. Childhood obesity: the new norm? U S Pharm. 2011;36(3):28-32.

47. Trevathan E, Dietz W. Obesity in neurology practice: a call to action. Neurology. 2009;73(9):654-655.

48. Davis NJ, Emerenini A, Wylie-Rosett J. Obesity management. Diabetes Educ. 2006;32(4):557-561.

49. Cheng TL, DeWitt TG, Savageau JA, O’Connor KG. Determinants of counseling in primary care pediatric practice: physician attitudes about time, money, and health issues. Arch Pediatr Adolesc Med. 1999;153(6): 629-635.

50. Power M, Cogswell ME, Schulkin J. Obesity prevention and treatment practices of US obstetrician-gynecologists. Obstet Gynecol. 2006; 108(4):961-968.

51. Patel AI, Madsen KA, Maselli JH, Cabana MD, Stafford RS, Hersh AL. Underdiagnosis of pediatric obesity during outpatient preventive care visits. Acad Pediatr. 2010;10(6):405-409.

52. Jay M, Gillespie C, Ark T, et al. Do internists, pediatricians, and psychiatrists feel competent in obesity care? J Gen Intern Med. 2008; 23(7):1066-1070.

53. Curran AE, Caplan DJ, Lee JY, et al. Dentists' attitudes about their role in addressing obesity in patients. J Am Dent Assoc. 2010;141(11): $1307-1316$

54. Molenaar EA, van Ameijden EJ, Vergouwe Y, Grobbee DE, Numans ME. Effect of nutritional counselling and nutritional plus exercise counselling in overweight adults: a randomized trial in multidisciplinary primary care practice. Fam Pract. 2010;27(2):143-150.

55. Kinsinger LS, JK, Kahwati L, Harvey R, et al. Design and dissemination of the MOVE! weight-management program for veterans. Prev Chronic Dis. 2009;6(3):A98. 
56. Brehm B, Rourke KM, Cassell C. Training health professionals: a multidisciplinary team approach in a university-based weight-loss program. J Allied Health. 1999;28(4):226-229.

57. Story MT, Neumark-Stzainer DR, Sherwood NE, et al. Management of child and adolescent obesity: attitudes, barriers, skills, and training needs among health care professionals. Pediatrics. 2002;110(1 Pt 2): $210-214$

58. Goff SL, Holboe ES, Concato J. Pediatricians and physical activity counseling: how does residency prepare them for this task? Teach Learn Med. 2010;22(2):107-111.

59. Hisaw T, Kerins C, McWhorter A, Seale N. Pediatric obesity curriculum in pediatric dental residency programs. Pediatr Dent. 2009;31:486-491.

60. Vetter ML, Sharon J, Herring M, Sood M, Shah NR, Kalet AL. What do resident physicians know about nutrition? An evaluation of attitudes, self-perceived proficiency and knowledge. J Am Coll Nutr. 2008;27(2): 287-298
61. Jay M, Schlair S, Caldwell R, Kalet A, Sherman S, Gillespie C. From the patient's perspective: the impact of training on resident physician's obesity counseling. J Gen Intern Med. 2010;25(5):415-422.

62. Gonzalez J, Gilmer L. Obesity prevention in pediatrics: A pilot pediatric resident curriculum intervention on nutrition and obesity education and counseling. J Natl Med Ass. 2006;98(9):1483-1488.

63. Stotland N, Haas JS, Brawarsky P, Jackson RA, Fuentes-Afflick E, Escobar GJ. Body mass index, provider advice, and target gestational weight gain. Obstet Gynecol. 2005;105(3):633-638.

64. Adams KM, Kohlmeier M, Powell M, Zeisel SH. Nutrition in medicine. Nutr Clin Pract. 2010;25(5):471-480.

65. Wolf C. Physician assistant students' attitudes about obesity and obese individuals. J Physician Assist Educ. 2010;21(4):37-40.
Journal of Multidisciplinary Healthcare

\section{Publish your work in this journal}

The Journal of Multidisciplinary Healthcare is an international, peerreviewed open-access journal that aims to represent and publish research in healthcare areas delivered by practitioners of different disciplines. This includes studies and reviews conducted by multidisciplinary teams as well as research which evaluates the results or conduct of such teams or

\section{Dovepress}

healthcare processes in general. The journal covers a wide range of areas and welcomes submission from practitioners at all levels, from all over the world. The manuscript management system is completely online and includes a very quick and fair peer-review system. Visit http://www.dovepress.com/testimonials.php to read real quotes from published authors.

Submit your manuscript here: http://www.dovepress.com/journal-of-multidisciplinary-healthcare-journal 